\title{
The regions of parametric instability of brush-contact device electromagnetic circuit in unstable working conditions
}

\author{
O. I. Kozyreva, I. V. Plokhov, Y. N. Guraviev, I. E. Savraev, A. V. Ilyin \\ Pskov State University, Electro mechanic Faculty. \\ Address: Russian Federation, Pskov, Lenin square, 2
}

\begin{abstract}
The method to determine parametric instability regions of the electromagnetic circuit of the secluded brush contact of brush-contact device with using the oscillation equation Mathieu II order for a dissipative system with one degree of freedom is developed. Recommendations on the selection of the parameters of the external damping device to eliminate the instability of electromagnetic waves in unstable working conditions brush-contact device are given.
\end{abstract}

Keywords: brush-contact device, sliding electrical contact, zone of parametric instability, damping device.

\section{INTRODUCTION}

Energy turbine generators have a constructive unit, called brush-contact device (BCD) or subassembly of the sliding electrical contact (SSEC). Reliability of the turbine generator is determined, including, reliable operation of this device. On the brush are acting significant dynamic forces that lead to mechanical disturbances and interruption current $[1,2]$. Also in the electrical circuits $\mathrm{BCD}$ arise electromagnetic resonance phenomena caused by the parametric modulation of the transition resistance and capacitance in the contact zone [3-6]. Described effect may cause increased brush-sparking, wear of contact parts, ring fire [7-10]. One of the important ways to reduce brush-sparking is the elimination of parametric resonance processes in electromagnetic circuits. To do this, we need to explore the regions of parametric instability of the oscillating system and to set appropriate limits on the functional parameters of the node [11-15]. We also will define characteristics of the external damping device to eliminate the instability of electromagnetic oscillations in unstable working conditions brush-contact device. These problems are important, since their decision will increase the reliability of $\mathrm{BCD}$ and of turbine generator as a whole.

In this paper the problem of constructing the regions of parametric instability of the electromagnetic vibrating system $\mathrm{BCD}$ of turbine generator is solved analytically. Also, a technique of selecting the parameters for the brush-contact device test stand is shown.

\section{MATERIALS AND METHODS}

Complete replacement scheme SSEC of the turbine generator is shown in Figure 1.

In this scheme:

$L_{b 1}, L_{b 2}, \ldots L_{b n} ; R_{b 1}, R_{b 2}, \ldots R_{b n}$ are the inductance and the electrical resistance of the secluded brush contact at the first slip ring;

$L_{b 1}^{\prime}, L_{b 2}^{\prime}, \ldots L_{b n}^{\prime} ; R_{b 1}^{\prime}, R_{b 2}^{\prime}, \ldots R_{b n}^{\prime}$ are the inductance and the electrical resistance of the secluded brush contact at the second slip ring;

$C_{r 1}, C_{r 2}, \ldots C_{r n} ; R_{r 1}, R_{r 2}, \ldots R_{r n}$ are the transition capacitance and the resistance of the secluded brush contact at the first slip ring (variables parameters); $C_{r 1}^{\prime}, C_{r 2}^{\prime}, \ldots C_{r n}^{\prime} ; R_{r 1}^{\prime}, R_{r 2}^{\prime}, \ldots R_{r n}^{\prime}$ are the transition capacitance and the resistance of the secluded brush contact at the second slip ring (variables parameters); $L_{r w 1}, R_{r w 1}$ are the inductance and the electrical resistance of the rotor winding;

$L_{e s}, R_{e s}, E_{e s}$ are the inductance, the electrical resistance and the electromotive force of energy supply of drive winding of the turbine generator; 


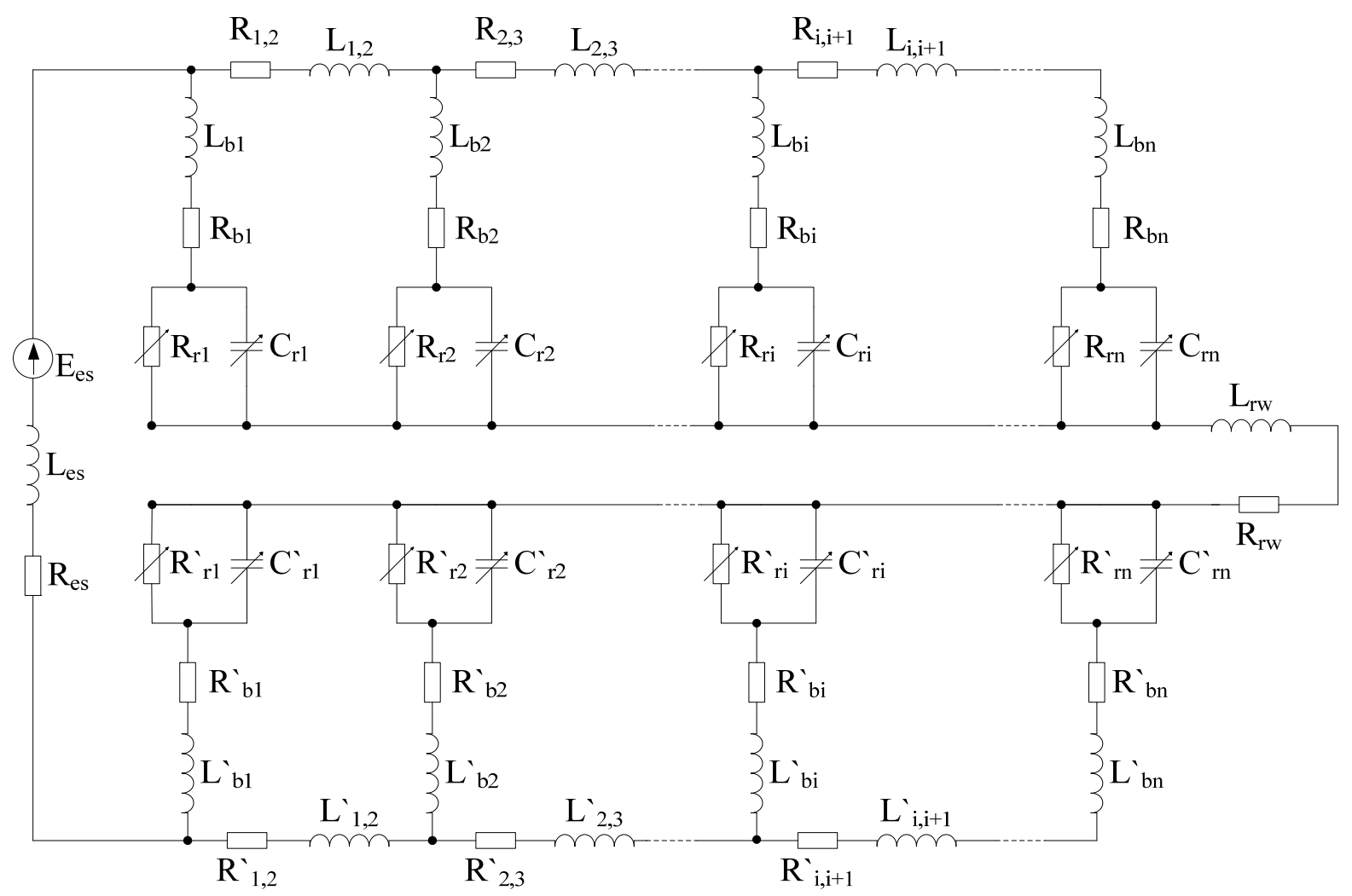

Fig. 1. The replacement scheme SSEC of the turbine generator.

$L_{1,2}, L_{2,3}, \ldots L_{i, i+1} ; R_{1,2}, R_{2,3}, \ldots R_{i, i+1} \quad$ are the inductance and the electrical resistance between the two secluded brush contacts at the first slip ring; $L_{1,2}, L_{2,3}, \ldots L_{i, i+1} ; R_{1,2}, R_{2,3}, \ldots R_{i, i+1} \quad$ are the inductance and the electrical resistance between the two secluded brush contacts at the first slip ring; $L_{1,2}^{\prime}, L_{2,3}^{\prime}, \ldots L_{i, i+1}^{\prime} ; R_{1,2}^{\prime}, R_{2,3}^{\prime}, \ldots R_{i, i+1}^{\prime} \quad$ - the inductance and the electrical resistance between the two secluded brush contacts at the second slip ring.

Consider the electrical processes in the electric circuit of the secluded brush contact. Equivalent circuit is shown in Figure 2.

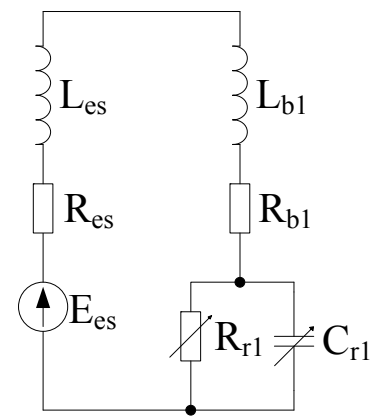

Fig. 2. Equivalent circuit of the secluded brush contact.

The operator expression for the electric resistance in this circuit is presented:

$$
Z_{1}(p)=L p+R+\frac{R_{r 1}}{1+R_{r 1} C_{r 1} p} .
$$

Then, the operator equation of the circuit is evident:

$$
\begin{aligned}
& L R_{r 1} C_{r 1} p^{2}+\left(L+R R_{r 1} C_{r 1}\right) p+\left(R+R_{r 1}\right) I_{1}= \\
& =\left(1+R_{r 1} C_{r 1} p\right) E_{v},
\end{aligned}
$$

where

$R=R_{b 1}+R_{e s}, L=L_{b 1}+L_{e s}$.

Linear differential equation II order with periodic coefficients is obtained by inverse Laplace transform. Voltage of winding excitation is given constant $E_{e s}=$ const :

$$
\begin{aligned}
& I^{\prime \prime}+\left(R / L+1 / R_{r 1} C_{r 1}\right) I^{\prime}+\left(1 / L C_{r 1}\right)\left(1+R / R_{r 1}\right) I= \\
& =\left(1 / L R_{r 1} C_{r 1}\right) E_{e s} .
\end{aligned}
$$

The research of the stability of the electromagnetic system, being described by the equation (1) is considered below.

The differential equation of the following form $A(t) \frac{d^{2} q}{d t^{2}}+B(t) \frac{d q}{d t}+C(t)=0$, generally describes the parametric vibrations of a linear system. The 
coefficients in this equation are dependent on parameters, that characterize the properties of parametric action. For certain values of the parameters, the solution may be unstable. A set of points form in the space of parameters regions of dynamic instability $[11,16,17]$. If the variable parameters are frequency of periodic parametric action, then the most interesting is the frequency ratio, called parametric resonance [11-17].

In this variant, oscillating motions are external parameters impact on the system. Vibrations are transmitted to the brush from the contact surface of the rotating collector ring. They entail periodic oscillations of the resistance and the capacitance of transition layer of the sliding contact $[3,4,9,10]$. If depth of modulation parameters of the transition layer is high, then the system may be in the region of parametric resonance (brush-sparking, ring fire).

To find the parametric resonances of the system, we will plot the boundary of instability, using oscillation equation Mathieu II order for a dissipative system with one degree of freedom [11].

Equation Mathieu has the form:

$$
I^{\prime \prime}+2 \varepsilon I^{\prime}+\omega_{0}^{2}(1+2 \mu \cos \omega t) I=0
$$

Lead the equation (1) to the form of the Mathieu equation (2). Assign $R=$ const, $L=$ const . We assume that the transition capacitance $C_{r 1}$ and the transition resistance $R_{r 1}$ of the secluded brush contact vary harmonically with the frequency $\omega$, amplitude $a_{r}, a_{c}$ and constant component $R_{0}, C_{0}$ [3-5]:

$$
\begin{aligned}
& R_{r 1}(t)=R_{0}\left(1 \pm \varepsilon_{R} \cos \omega t\right) ; \\
& C_{r 1}(t)=C_{0}\left(1 \pm \varepsilon_{C} \cos \omega t\right),
\end{aligned}
$$

where $\varepsilon_{R}=a_{R} / R_{0}, \varepsilon_{C}=a_{C} / C_{0}$ are the parameters of the modulation depth $\varepsilon_{R}, \varepsilon_{C} \ll 0$.

Approximately find the coefficients for the Mathieu equation [11, 16, 17]:

$\omega_{0}$ is the natural frequency of electromagnetic oscillations in this circuit,

$$
\omega_{0}^{2}=\frac{1}{L C_{0}}\left(1+R / R_{0}\right) ;
$$

$\mu$ is the total modulation depth of the oscillating circuit (excitation coefficient),

$$
2 \mu=\varepsilon_{C}+\varepsilon_{R} \frac{R}{R+R_{0}} ;
$$

$\varepsilon$ is the damping parameter of electromagnetic oscillations (dissipation),

$$
2 \varepsilon=\frac{R}{L}+\frac{1}{R_{0} C_{0}} ;
$$

$\omega$ is the frequency of parametric action (frequency of vibrations).
Plot the boundary of instability for the dissipative system on in the plane $\mu, \eta=\omega / 2 \omega_{0}$. For calculation boundaries of instability are taken the following formulas. For the first instability region (basic parametric resonance):

$$
\omega \simeq 2 \omega_{0} \sqrt{1 \pm \sqrt{\mu^{2}-(v / \pi)^{2}}}
$$

For the second instability region:

$$
\omega \simeq \omega_{0} \sqrt{1-\mu^{2} \pm \sqrt{\mu^{4}-\left(1-\mu^{2}\right)(v / \pi)^{2}}},
$$

where $v=2 \pi \varepsilon / \omega_{0}-$ decrement of free oscillations.

\section{RESULTS AND DISCUSSION}

For calculations the parameters of the brushcontact device test stand are taken (Tables 1) [1820].

Tables 1

\begin{tabular}{|c|c|c|c|c|}
\hline \multicolumn{5}{|c|}{ The parameters of the test stand } \\
\hline $\mathrm{R}_{\mathrm{sv}}, \Omega$ & $\mathrm{L}_{\mathrm{sv}}, \mathrm{mH}$ & $\mathrm{R}_{\mathrm{b} 1}, \mathrm{~m} \Omega$ & $\mathrm{L}_{\mathrm{b} 1}, \mathrm{nH}$ & $\varepsilon_{\mathrm{R}}, \varepsilon_{\mathrm{C}}$ \\
\hline 1.3 & 0.3 & 0.8 & 75 & 0.5 \\
\hline
\end{tabular}

Calculations for several values $R_{0}, C_{0}$ are given in Tables 2:

Tables 2

\begin{tabular}{|c|c|c|c|c|}
\hline \multicolumn{5}{|c|}{ Calculations data } \\
\hline $\mathrm{C}_{0}, \mathrm{nF}$ & $\mathrm{R}_{0}, \Omega$ & $\omega_{0}, \mathrm{rad} / \mathrm{s}$ & $\varepsilon$ & $v$ \\
\hline 200 & 40 & $1.31 \mathrm{E}+05$ & $5.21 \mathrm{E}+04$ & 2.507 \\
\hline 200 & 70 & $1.30 \mathrm{E}+05$ & $3.79 \mathrm{E}+04$ & 1.827 \\
\hline 200 & 90 & $1.30 \mathrm{E}+05$ & $3.00 \mathrm{E}+04$ & 1.447 \\
\hline 200 & 200 & $1.30 \mathrm{E}+05$ & $1.47 \mathrm{E}+04$ & 0.712 \\
\hline
\end{tabular}

According to the calculations we plot graphs in Fig. 3



Fig. 3. The instability regions for equivalent circuit of the brushcontact device test stand:

1 and $1^{\prime}$ are the boundaries of the first and the second instability regions, $R_{0}=200 \Omega ; 2$ and 2 are the boundaries of the first and the second instability regions, $R_{0}=90 \Omega ; 3$ and $3{ }^{`}$ are the boundaries of the first and the second instability regions, $R_{0}=70 \Omega ; 3$ and $3^{`}$ are the boundaries of the first and the second instability regions, $R_{0}=40 \Omega$. 
As can be seen from the graphs, the instability region appears at a sufficiently high resistance value $R_{0}$. With the growth of $R_{0}$, the boundaries of the instability regions shift toward lower values of the modulation.

A similar calculation for several values of the transition capacitance $C_{0}$ shows that there is an inverse relationship: at the growth of $C_{0}$, the boundaries of the instability regions shift toward high values of the modulation.

Analysing the instability regions with value of the modulation factor calculated by the formula (4), we can see whether the processes of circuit stability.

Calculated modulation factor for the circuit $\mu=0.256$. Thus, EM circuit gets into the region of parametric resonance when $R_{0}=180 \Omega$, Fig 4 .

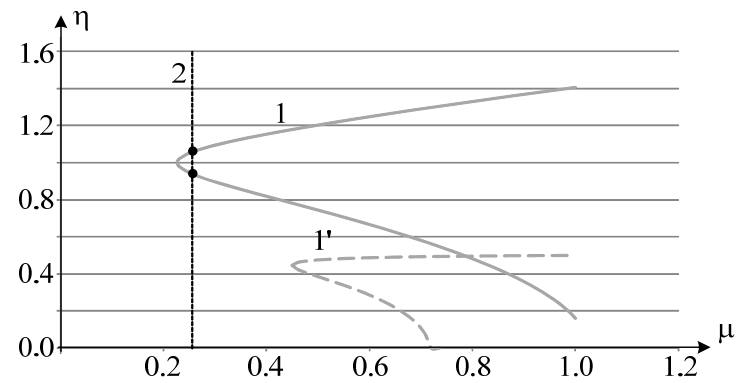

Fig. 4. The instability regions for the equivalent circuit of the brush-contact device test stand:

1 and 1 ' are the boundaries of the first and the second instability regions, $R_{0}=200 \Omega ; 2$ is the line $\mu=0.256$.

According to Fig.4 define the values of the decrement of free oscillations $v=2 \pi \varepsilon / \omega_{0}$, in which the circuit will be unstable.

Tables 3

\begin{tabular}{|l|c|c|r|}
\hline \multicolumn{4}{|c|}{ Values determined from Figure 4} \\
\hline & $\eta$ & $\omega, \mathrm{rad} / \mathrm{s}$ & $\mathrm{f}, \mathrm{kHz}$ \\
\hline start value & 1.0577 & $2.74 \mathrm{E}+05$ & 43.6 \\
\hline final value & 0.9387 & $2.43 \mathrm{E}+05$ & 38.69 \\
\hline
\end{tabular}

So, if the frequency of external vibrations will be in the range from $43.6 \mathrm{kHz}$ to $38.69 \mathrm{kHz}$ investigated circuit will be unstable.

Thus, we have found the possible regions of parametric instability with the frequency of vibrations $\omega$ for the electromagnetic circuit of secluded brush contact, for given values of the total modulation depth $\mu$, of the natural frequency of electromagnetic oscillations $\omega_{0}$ and of the dissipation $\varepsilon$.

To exclude the parametric resonance should be avoided working condition in which mean values of transition capacitance and resistance of sliding contact exceeds allowed value.
Whenever it is impossible we propose the introduction in the electromagnetic circuit the external damping device [21]. Its main element is the additional capacitor installed between the working brush and the slip ring.

The equivalent circuit and the calculations of EM circuit with the additional capacitor for the secluded brush contact are presented.

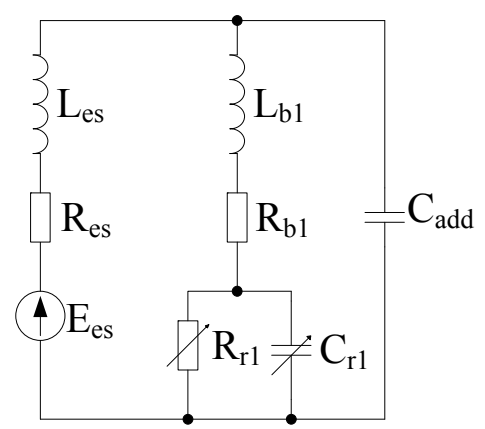

Fig. 5. The equivalent circuit of the secluded brush contact with the additional capacitor.

For this circuit the linear differential equation II order with periodic coefficients in the form of the Mathieu equation (2) is offered:

$$
\begin{aligned}
& I^{\prime \prime}+\left(R_{e s} / L_{e s}+1 / R_{r 1}\left(C_{r 1}+C_{a d d}\right)\right) I^{\prime}+ \\
& +\left(1 / L_{e s}\left(C_{r 1}+C_{a d d}\right)\right)\left(1+R_{e s} / R_{r 1}\right) I= \\
& =\left(1 / L_{e s} R_{r 1}\left(C_{r 1}+C_{a d d}\right)\right) E_{e s},
\end{aligned}
$$

Where

$R_{e s} \simeq R, L_{e s}=L$

The coefficients for the Mathieu equation are evident:

$$
\begin{gathered}
\omega_{0}^{2}=\frac{1}{L\left(C_{r 1}+C_{a d d}\right)}\left(1+R_{e s} / R_{r 1}\right) ; \\
2 \varepsilon=\frac{R_{e s}}{L_{e s}}+\frac{1}{R_{r 1}\left(C_{r 1}+C_{a d d}\right)} .
\end{gathered}
$$

The parameters of the brush-contact device test stand with the additional capacitor $\mathrm{C}_{\text {add }}$ for the plot instability regions are given in Tables 1, 5 [18-20].

Tables 4

\begin{tabular}{|c|c|c|c|c|}
\hline \multicolumn{5}{|c|}{ The parameters of test stand } \\
\hline $\mathrm{R}_{\mathrm{sv}}, \Omega$ & $\mathrm{L}_{\mathrm{sv}}, \mathrm{mH}$ & $\mathrm{R}_{\mathrm{b} 1}, \mathrm{~m} \Omega$ & $\mathrm{L}_{\mathrm{b} 1}, \mathrm{nH}$ & $\varepsilon_{\mathrm{R}}, \varepsilon_{\mathrm{C}}$ \\
\hline 1.3 & 0.3 & 0.8 & 75 & 0.5 \\
\hline
\end{tabular}

According to the calculations we plot graphs in Fig. 5. 


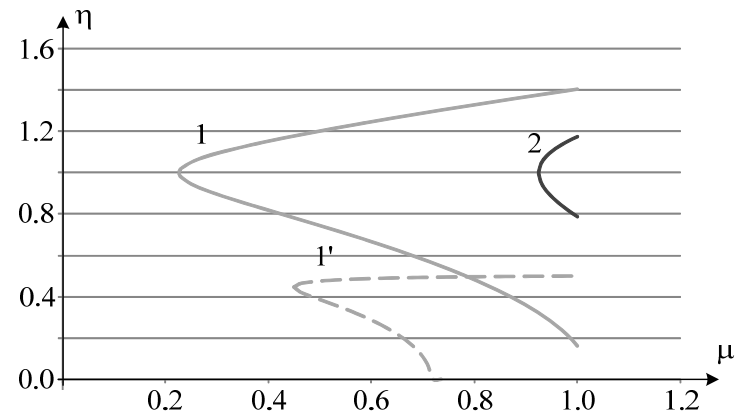

Fig. 5. The instability regions for the equivalent circuit of brushcontact device test stand with the additional capacitor:

1 and 1 are the boundaries of the first and the second instability regions, $R_{0}=200 \Omega ; 2$ is the boundary of the first instability region for the test stand with the additional capacitor $C_{\text {add }}$.

As can be seen from the graphs when we add the additional capacitor the boundary of instability region shifts toward higher values of the modulation.

Calculated modulation factor for the circuit $\mu=0.256$. Thus, circuit with the additional capacitor is not gets into a region of parametric resonance. By increasing the value of additional capacitor, the instability regions completely disappear.

\section{CONCLUSION}

In electrical circuits brush-contact device arise electromagnetic resonance effects, which may cause increased brush-sparking and wear, as well as a ring fire. This occurs when the frequency of parametric mechanical modulation of the transition resistance and the transition capacitance of sliding contact coincides with natural oscillations of EM circuit of brush-contact device.

We have developed the method to determine parametric instability regions of the electromagnetic circuit of the secluded brush contact of brush-contact device, leaning upon the following parameters:

- the frequency of parametric action (frequency of modulation of parameters of transition layer) $\omega$;

- the total modulation depth of the oscillating circuit of transition capacitance and resistance in the contact zone $\mu$;

- the natural frequency of electromagnetic oscillations in circuit of the secluded brush contact, $\omega_{0}$;

- the damping parameter of electromagnetic oscillations $\varepsilon$.

Recommendations on the selection of the parameters of the external damping device to eliminate the instability of electromagnetic oscillations in unstable working conditions brushcontact device are given.

\section{REFERENCES}

[1] Механика скользящего контакта / В.И.Нэллин, Н.Я.Богатырев, Л.В.Ложкин и др. - М.:Транспорт. 1966.

[2] Кончиц В.В., Мешков В.В., Мышкин В.В. Триботехника электрических контактов. Минск: Наука и техника. 1986.

[3] Плохов И. В. Комплексная диагностика и прогнозирование технического состояния узлов скользящего токосъёма турбогенераторов. Диссертация доктора технических наук. - СПб: СПбГПУ, 2001.

[4] Плохов И. В. Модель динамики токопередачи через скользящий контакт // Электротехника. - М., 2005. №2. - C. 28-33

[5] Ильин А. В., Плохов И. В., Козырева О. И. Моделирование процессов электрофрикционного взаимодействия в узлах скользящего токосъема. // Научно-технический вестник Поволжья. - Казань: Научно-технический вестник Поволжья, 2013. - №4. C. $166-173$

[6] Ильин А. В., Плохов И. В., Козырева О. И. Моделирование микрорельефа поверхностей контактирующих деталей. // Научно-технический вестник Поволжья. - Казань: Научно-технический вестник Поволжья, 2013. - №5. - C. 180-183

[7] Holm P. Theory of the sparking during communication on dynames // IEEE Transactions on Power Apparatus and System. - 1962. - No. 63. - P. 588-590.

[8] Хольм Р. Электрические контакты. - М.: Иностранная литература, 1961.

[9] Greenwod J.A. Constriction resistance and the real area of contact. - British Journal off appl. Physics. 1966. V.17. P.1621-1631.

[10] Yip F.C., Venart J.E.S. Surface topography effects in the estimation of thermal and electrical contact resistance. - In: Proc. Inst. Mech. Eng., 1968. V. 182. Pt. 3K. P. 81.

[11] Вибрации в технике, т.1, М.: «Машиностроение», 1978 г., c. 121.

[12] Мандельштам Л. И. Лекции по теории колебаний, М., 1972.

[13] Мандельштам Л. И. Основы теории колебаний, 2 изд., M., 1988.

[14] Рабинович М. И., Трубецков Д. И. Введение в теорию колебаний и волн, М., 1984.

[15] Мэтьюз Дж., Уокер Р. Математические методы в физике. Пер. с англ., М., Атомиздат, 1972, 392 с.

[16] Паровик Р.И. Диаграммы Стретта-Айнса для обобщенного уравнения матье. Вестник КРАУНЦ. Физ.-мат. науки. - 2012. - № 1(4). - С. 29-30 - ISSN 2079-6641.

[17] McLachlan, N. W., Theory and Application of Mathieu Functions, Clarendon Press, Oxford, 1947.

[18] Лившиц П.С. Справочник по щеткам электрических машин. М.:Энергоатомиздат. 1983.

[19] Веселовский В. С. Угольные и графитовые конструкционные материалы, М., 1966.

[20] Шулепов С. В., Физика углеграфитовых материалов, М., 1972.

[21] Устройство для уменьшения искрообразования в узле скользящего токосъема / Плохов И.В., Ильин А.В., Исаков А.Н., Козырева О.И. // Патент на полезную модель RU132630, опубл. 2013.09.20. 